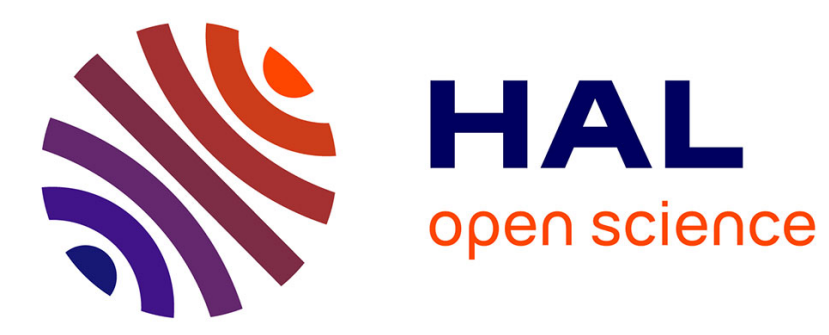

\title{
Effects on milk yield and composition of infusions of graded levels of glucose into the duodenum of dairy cows
}

Catherine Hurtaud, R Vérité, H Rulquin

\section{To cite this version:}

Catherine Hurtaud, R Vérité, H Rulquin. Effects on milk yield and composition of infusions of graded levels of glucose into the duodenum of dairy cows. Annales de zootechnie, 1994, 43 (3), pp.309-309. hal-00889048

\section{HAL Id: hal-00889048 \\ https://hal.science/hal-00889048}

Submitted on 1 Jan 1994

HAL is a multi-disciplinary open access archive for the deposit and dissemination of scientific research documents, whether they are published or not. The documents may come from teaching and research institutions in France or abroad, or from public or private research centers.
L'archive ouverte pluridisciplinaire HAL, est destinée au dépôt et à la diffusion de documents scientifiques de niveau recherche, publiés ou non, émanant des établissements d'enseignement et de recherche français ou étrangers, des laboratoires publics ou privés. 


\title{
Effects on milk yield and composition of infusions of graded levels of glucose into the duodenum of dairy cows
}

\author{
C Hurtaud, R Vérité, $H$ Rulquin
}

INRA, Station de Recherches sur la Vache Laitière, 35590 Saint-Gilles, France

Increased glucose or propionic acid availability may decrease milk fat content according to the glucogenic theory but it does not affect milk protein yield (Hurtaud et al, 1993). The objective of our experiment was the establishment of a law of response of protein content/fat content ratio to postruminal glucose supply.

Three continuous duodenal infusions of glu$\operatorname{cose}(500,750$ or $1500 \mathrm{~g} / \mathrm{d})$ were compared with water as control. Four ruminally and duodenally fistulated Holstein cows (7 weeks in lactation) were used in a $4 \times 4$ latin square ( 2 weeks/period). The basal diet $(51.2 \%$ maize silage, $16.3 \%$ dehydrated alfalfa, $25.1 \%$ energy concentrate and $7.4 \%$ soybean meal) was fed proportionally to the energy infused so that energy and nitrogen needs were met. The composition of energy concentrate was $15 \%$ wheat, $15 \%$ corn, $15 \%$ barley, $20 \%$ wheat bran, $25 \%$ sugar beet pulp, $1 \%$ fat, $5 \%$ molasses and $4 \%$ mineral salts. Milk fat and protein contents were measured every day and blood was sampled $1 \mathrm{~h}$ before moming feeding on the last day of each period.

Increasing levels of glucose did not affect milk yield but decreased milk fat yield and content $(P<0.05)$ and tended to increase milk protein yield and content. Milk casein also tended to increase (table I). Infusing $750 \mathrm{~g} / \mathrm{d}$ of glucose seemed to result in minimum fat content and yield. By contrast, the maximum protein yield and content could have been higher with an infusion level exceeding $1500 \mathrm{~g} / \mathrm{d}$ glucose. With an increased level of glucose infusion, 3-hydroxybutyrate and non-esterified fatty acids contents were decreased $(P<0.05)$ while glucose and insulin levels remained the same.

Glucose infusion gave classical results, ie a large decrease in fat yield and content and no change in protein yield. These results confirm the lack of response of protein yield with either isoenergetic infusions of glucose or VFA (Hurtaud et al, 1993). The highest protein content/fat content ratio seemed to be obtained after addition of $750 \mathrm{~g} / \mathrm{d}$ glucose. Future studies using longer periods of glucose infusion ( $>2$ weeks) are required to confirm these results especially for protein content (Rook and Balch, 1961) and to identify metabolic changes.

Hurtaud C, Rulquin H, Vérité R (1993) J Dairy Sci 76, 3011-3020

Rook JAF, Balch CC (1961) Br J Nutr 15, 361369

Table I. Effect of different levels of glucose on milk yield and composition.

\begin{tabular}{lccccc}
\hline Glucose infusion $(g / d)$ & 0 & 500 & 750 & 1500 & $S E$ \\
\hline & & & & & \\
Energy intake (MJ NEL) & 130.9 & 137.8 & 135.4 & 145.0 & 9.0 \\
Milk yield $(\mathrm{kg})$ & 38.0 & 38.2 & 37.5 & 37.8 & 1.0 \\
Fat $(\mathrm{g} / \mathrm{kg})$ & $40.9 \mathrm{a}$ & $37 . \mathrm{b}^{\mathrm{b}}$ & $35.4 \mathrm{c}$ & $34.8 \mathrm{c}$ & 0.7 \\
Protein $(\mathrm{g} / \mathrm{kg})$ & 28.0 & 28.0 & 28.4 & 28.8 & 0.7 \\
Casein $(\mathrm{g} / \mathrm{kg})$ & 22.7 & 23.1 & 23.3 & 23.6 & 0.7 \\
& & & & & \\
\hline
\end{tabular}

a, b Within-line means with different subscripts differ $(P<0.05)$. 